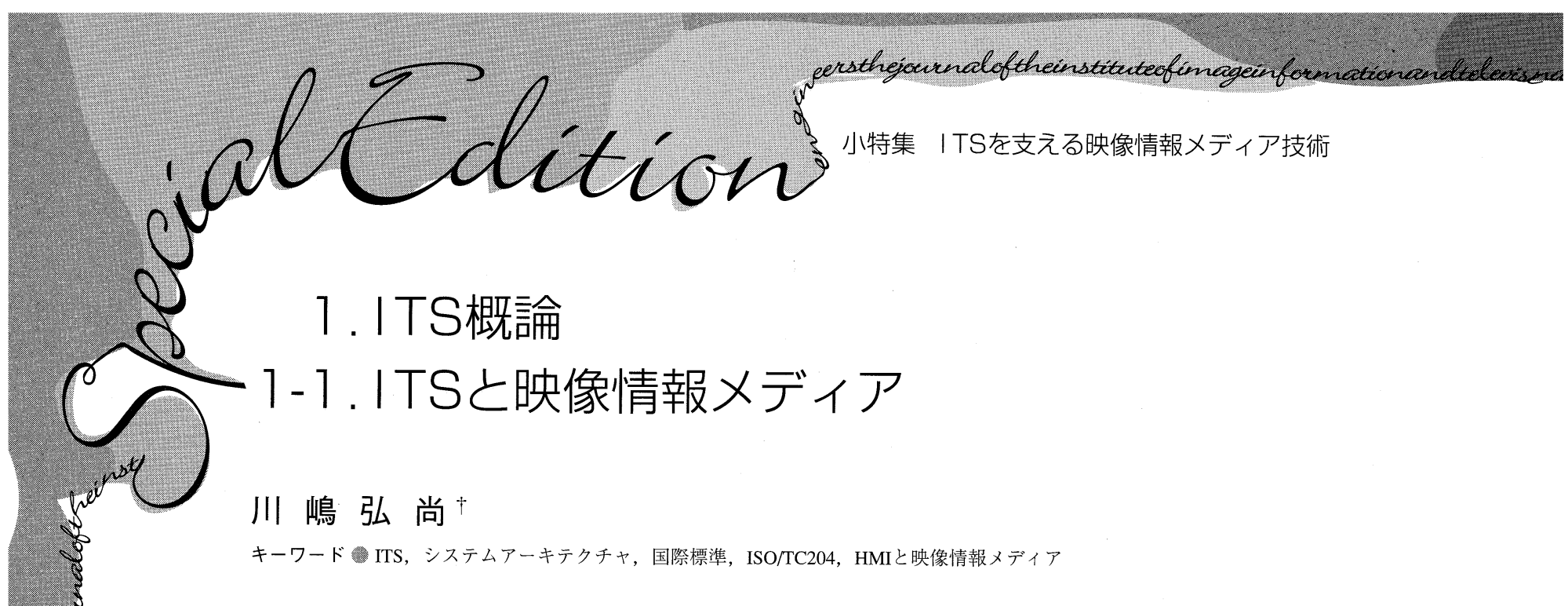

1.まえがき

ITS (Intelligent Transport Systems) とは何かを定義す ることは実は容易ではない。要素技術やこれらを組合せた システム技術は，技術の進歩や社会の要請によって変化し， ITSを大きく変えることになる．また道路交通以外の鉄道， 航空，海運でもITSのプロジェクトが進展している国々も ある.さらに，道路交通と他の交通機関との結接部（イン タモーダル)のオペレーションに関しても, ITSの重要な適 用場面と考えられている.

したがって，ITSを記述するには，広範囲かつ重層的な 概念を導入する必要がある。幸いITSでは，システムアー キテクチャという重層的な記述方法を用いて, システムの 機能とそのインタフェースを表現している。 そこで本稿で は，システムアーキテクチャを用いてITSの概略を説明し， システム技術や，インタフェース技術の動向については, ITSの国際標準を策定しているISOの活動を参照しながら 説明したい。最後に映像情報とITSの関連についてまとめ てみた。

ITSの目的，目標は何かとなれば，抽象的ではあるが， きわめて明解な答を各国とも用意している。一番最近に改 訂されたという点から，米国の例を引用してみる1).

“ITSのミッションは, ITC (情報通信) 技術を使って，人 と物と情報に関して, 安全で, 効率的な方法によって運 輸・交通を活性化するシステムを創造することである。そ の際の制約は，高いモビリティの確保，高い燃料効率，低 い污染，高い操業効率である."

さらに具体的なゴールを6つ挙げている.

(1) 運輸・交通システムの容量を高め，操業効率を上げる

（2）個人のモビリティや，利便性，快適性を高める

(3) 安全性の向上

（4）環境コストとエネルギー消費を抑制する

（5）個人および企業の生産性を上げ，経済全体の活性化 に寄与する

（6）ITSの開発と普及が進展するような環境を創造する

\section{†慶應義熟大学 理工学部}

"Introduction : Intelligent Transport Systems and Image Information" by Hironao Kawashima (Faculty of Science and Technology, Keio University, Yokohama)

\section{ITSのシステムアーキテクチャ}

もともとコンピュータの世界で知られていたシステムア ーキテクチャという概念をITSの領域に持ち込んだのは米 国運輸省である。1990年代当時，軍艦などの兵器システム の開発，オペレーション，メンテナンスに偉力を発揮し， ITCを活用したペーパレス環境を構築する上で相当の実績 をあげていたＩTSも巨大なシステムであること，州政府 と連邦政府との利害を調整するために枠組が必要であった こと，交通行政，オペレーション全般に亘ってIT化が強く 望まれていたこと等が，導入の背景と思われる.

米国の後を追う形で日本，欧州委員会がそれぞれシステ ムアーキテクチャをとりまとめて発表している。また $\mathrm{EU}$ の数ヶ国をはじめ, 豪州, 中国, 韓国もシステムアーキテ クチャやこれに類する文書のとりまとめを行っている.

システムアーキテクチヤの策定は，まず利用者サービス をサブサービスに分解して詳細定義を行う。これをもとに

\begin{tabular}{|c|c|}
\hline \multicolumn{2}{|c|}{ 表1 利用者サービスの詳細定義 } \\
\hline (開発分野) & （利用者サービス） \\
\hline \multirow[t]{2}{*}{ 1.ナビゲーションシステムの高度化 } & （1）交通関連情報の提供 \\
\hline & (2) 目的地情報の提供 \\
\hline 2. 自動料金収受システム & （3）自動料金収受 \\
\hline \multirow[t]{4}{*}{ 3. 安全運転の支援 } & (4) 走行環境情報の提供 \\
\hline & （5）危険警告 \\
\hline & (6) 運転補助 \\
\hline & (7) 自動運転 \\
\hline \multirow[t]{2}{*}{ 4. 交通管理の最適化 } & (8) 交通流の最適化 \\
\hline & （9）交通事故時の交通規制情報の提供 \\
\hline \multirow[t]{3}{*}{ 5. 道路管理の効率化 } & (10)維持管理業務の効率化 \\
\hline & (11)特殊車両等の管理 \\
\hline & (12) 通行規制情報の提供 \\
\hline \multirow[t]{2}{*}{ 6. 公共交通の支援 } & (13) 公共交通利用情報の提供 \\
\hline & (14) 公共交通の運行·運行管理支援 \\
\hline \multirow[t]{2}{*}{ 7. 商用車の効率化 } & (15) 商用車の運行管理支援 \\
\hline & （16）商用車の連続自動運転 \\
\hline \multirow[t]{2}{*}{ 8. 歩行者等の支援 } & (17)経路案内 \\
\hline & (18)危険防止 \\
\hline \multirow[t]{3}{*}{ 9. 緊急車両の運行支援 } & (19) 緊急時自動通報 \\
\hline & (20) 緊急車両経路誘導·救援活動支援 \\
\hline & （21）高度情報通信社会関連情報の利用 \\
\hline
\end{tabular}

映像情報メディア学会誌 Vol. 59, No. 6, pp. 812〜817 (2005) 


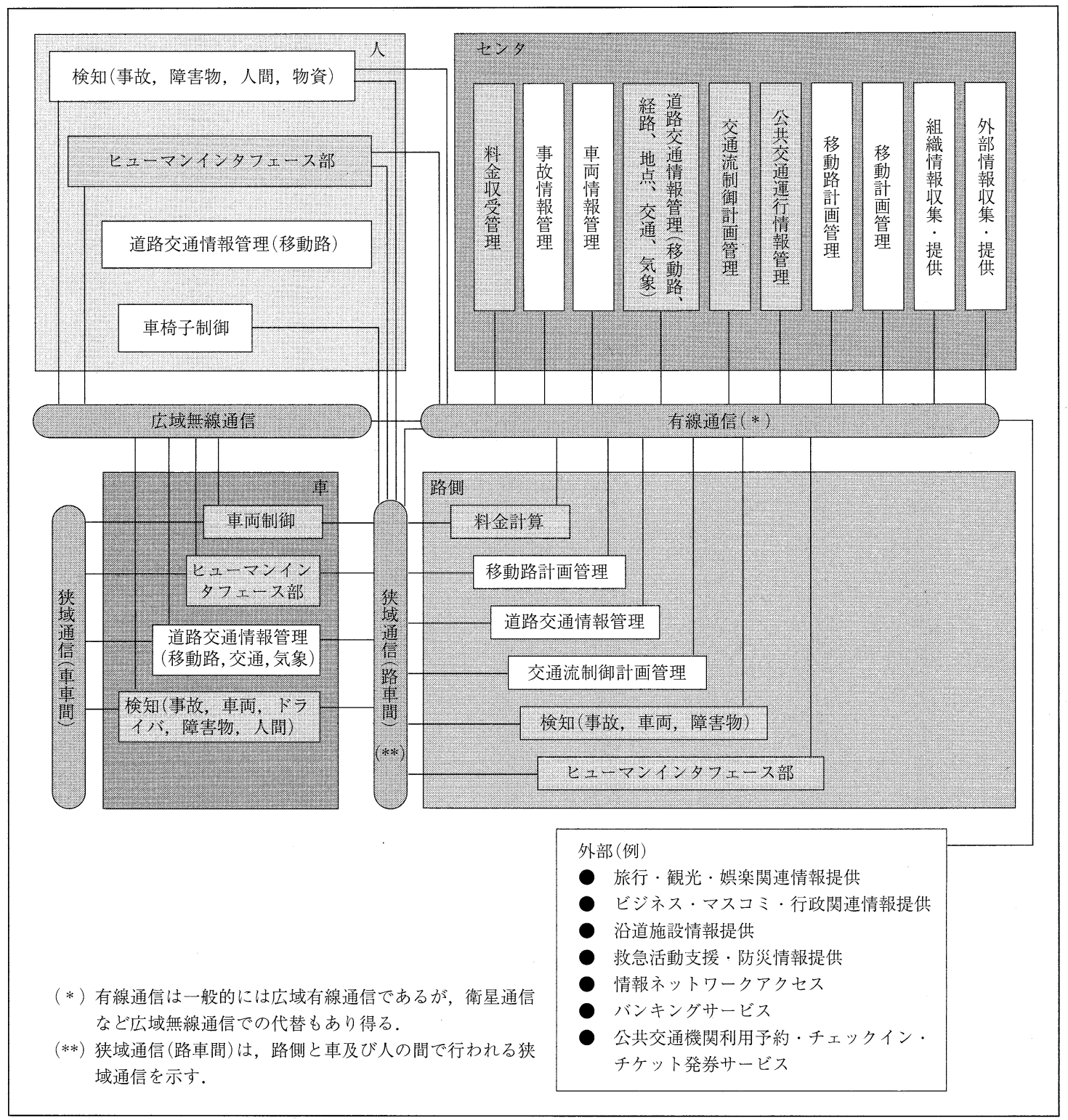

図1 システムアーキテクチャにおけるサブシステムの相互接続図

(出典：(財) 道路新産業開発機構：ITS Hand book 2003-2004)

論理アーキテクチャを策定する．次にサービス間で共有で きる機能や情報を論理アーキテクチャから抽出しモデル化 したサブシステムを定義し，物理アーキテクチャを策定す る．ITS全体を俯瞰するためにサブシステムの相互接続図 を作成するこのことによって，ITSを統合的なシステム として効率良く構築しようというものである.

詳細は紙幅の制約から紹介できないが，興味のある方は 文献10）11）を見ていただくとして，ここでは日本のシステ ムアーキテクチャで定義されている利用者サービス，サブ システムの相互接続図を，表1と図1に挙げておく。また， 米国のナショナルアーキテクチャで定義されているユーザ サービスの一覧とサブシステムの接続図を，参考のため， 表2，図2に挙げておく、日本にはないシステムや制度があ るため原文のままとした。
日米とも，ほほ同じような結果となっているが，システ ムアーキテクチヤに関する方法論が日米で異なっているこ とは興味深い. 米国は現場での普及を考えて構造化分析手 法を採用しているが，日本は搪張性を考えてオブジェクト 指向分析手法を採用している．しかし，重要なことはこれ らの枠組をどのように現実に適用していくかということで ある。例えば，ここで定義されたサービスは行政が一部ま たは全部の責任を負うべきシステムが総合的にまとめられ ているのであって，ITSのすべてではない，派生する民間 サービスを規定するものではなく, むしろ規制緩和・改革 をなお一層推し進める必要があることを示している．日米 に打ける行政システムの差が, 実現されるITSに大きな影 響を与える由縁である。 


\section{ITSの国際標準}

ISO/TC204（ITS）ではITSの一部の分野，例えば通信メ ディアの物理層, センサ, アクチュエータ等の要素技術そ のものについては扱っていないが, 日米のシステムアーキ テクチャで扱っているシステムの大部分を対象としてい る. 航空, 船舶, 鉄道については別のTCで扱うことにな っているが，インタモーダル機能やテロ等に対するセキュ リティ機能の国際標準については, TCを超えた枠組が議 論されている.

車と道路交通のインタフェースが中心であるが, ITSの システム技術と車両技術の境界は一義的に決められるもの ではなく, 作業項目ごとにTC22 (自動車) と相談しながら 決めていくことになる.

ISO/TC204 (ITS) は，1993年に米国の発議でスタートし， TCの下に直接WGが存在する機動性を重視した組織となっ ていて, 現在12のWGが活発な活動を行っている(表3, 表4).

ITSの進展に伴って, 国際標準に関連した他の国際機関と の連携が増大している．いくつか代表的な例を挙げてみる.

地図データベースやGISに関する国際標準を扱うTC211 とTC204のWG3とは連絡を密に行っている. 地図そのもの を携帯電話を使って配信することが可能になってきたの で, ナビの地図更新 (道路工事, 道路建設, 交通規制等) と 共通の技術構造を持っていることが認識され，両者の間で 役割分担を含めた議論が行われている. OGC (Open GIS Consortium)のメンバも参加しているので, デファクトス タンダードとの連携も充分考慮されていると考えている.

電子タグを扱っているISO/IEC JTC1 SC31とは，DSRC (Dedicated Short Range Communication) の物流への応用 として, AVI (Automatic Vehicle Identification), AEI (Automatic Equipment Identification) という作業項目を

表3 ISO/TC204の国内組織と活動状況（出典：（財）自動車研究所：ITSの標準化2005）

\begin{tabular}{|c|c|c|c|c|c|c|c|c|}
\hline 分科会 & 事務局 & PWI & NP & WD & $\mathrm{CD}$ & DIS & FDIS & ISO \\
\hline "システム機能構成分科会 (WG1) & (財) 日本自動車研究所 & 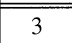 & & 3 & & & & 1 \\
\hline ITSデータベース技術分科会（WG3） & （財）日本デジタル道路地図協会 & 2 & 1 & 2 & & & & 1 \\
\hline 車両·貨物自動認識分科会 (WG4) & （社）新交通管理システム協会 & & & 7 & 1 & 3 & & \\
\hline 料金収受分科会（WG5） & （財）道路新产業開発機構 & & & 2 & 1 & & & \\
\hline 商用車運行管理分科会 (WG7) & (財) 道路保全技術センター & & & 1 & 1 & & & \\
\hline 公共交通分科会（WG8） & (財) 国土技術研究センター & 3 & & 2 & & & & \\
\hline 交通管理分科会（WG9） & （社）新交通管理システム協会 & 6 & & & & & & \\
\hline 旅行者情報分科会（WG10） & （社）新交通管理システム協会 & 2 & 1 & 8 & 1 & & 1 & 2 \\
\hline ナビ・経路誘導分科会 (WG11) & （社）自動車技術会 & 1 & & & & & & 1 \\
\hline 走行制御分科会（WG14） & （社）自動車技術会 & 4 & & 2 & & & & 3 \\
\hline 狭域通信分科会（WG15） & （社）電子情報技術産業協会 & & 1 & & & & 1 & \\
\hline 広域通信分科会（WG16） & （社）電子情報技術産業協会 & 4 & 1 & 2 & 2 & & & \\
\hline
\end{tabular}

PWI：Preliminary Work Item（予備作業項目）

$\mathrm{CD}$ ：Committee Draft $(\mathrm{s})$ (委員会原案)

NP : New Work Item Proposal（新作業項目提案）

DIS : Draft International Standard（国際規格案）

WD : Working Draft (s) (作業原案)

FDIS : Final Draft International Standard（最終国際規格案）

ISO : International Standard（国際規格） 


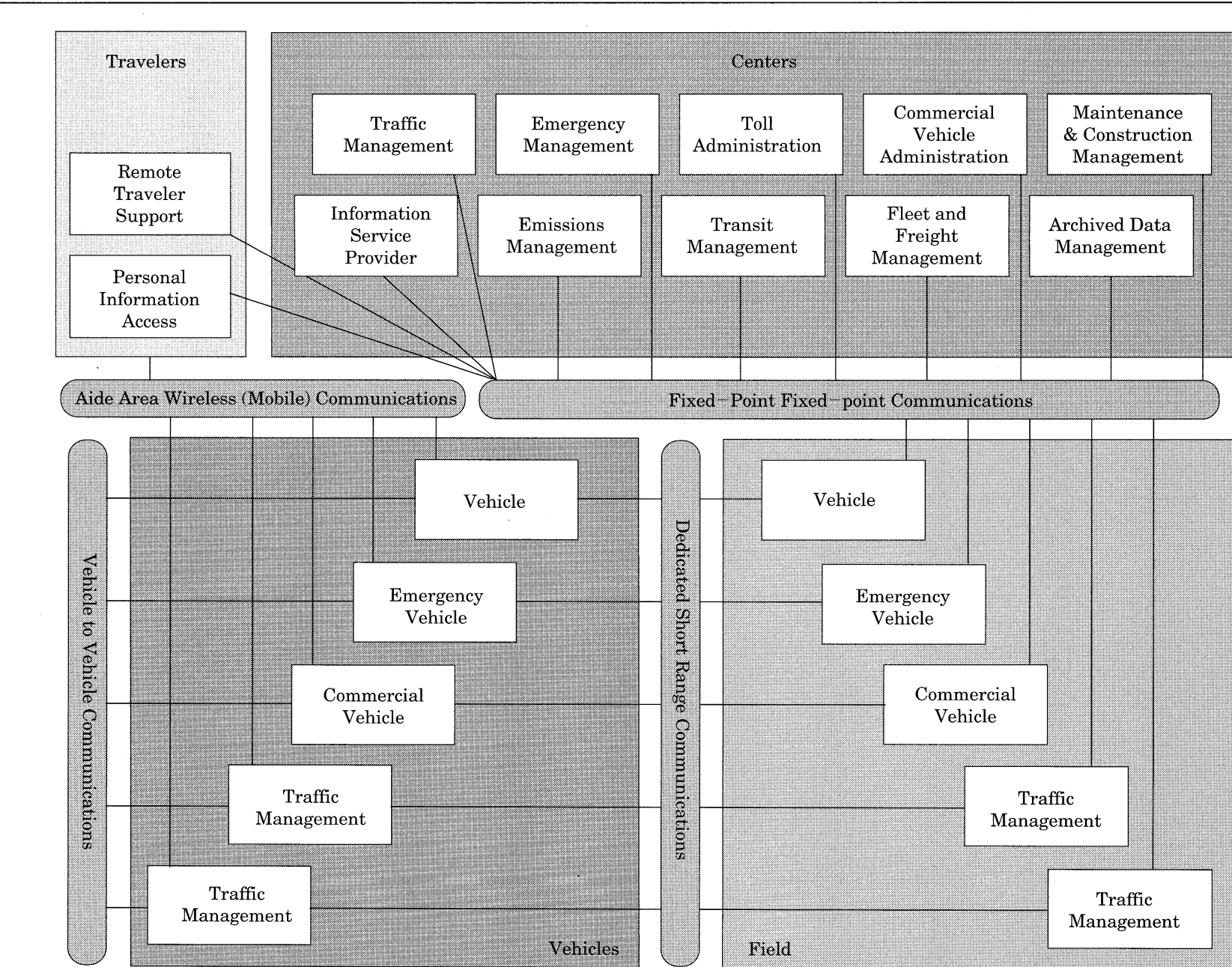

図2 米国システムアーキテクチャにおけるサブシステムの相互接続図 (出典 : Key Concepts of the National ITS Architecture)

通じて，TC204のWG4,WG5が情報交換を行っている。

WG16で作業項目となっているCALM (Communication Air-interface Long and Medium range) では，1Gから3Gま での携帯電話，DSRC，赤外線通信，ミリ波通信等の中広 狭域通信をITSに活用する場合に必要なアプリケーション インタフェースの構築を目指している.

日本で開発されたDSRC (ARIB T-75) をIP接続可能にし たASL技術 (ARIB-T88) は，ITU (International Telecommunication Union)に提案されると同時に，CALMにも提 案されている.DSRCの物理層は現在地域や国の電波行政 にしたがって複数のプロファイルが存在するが，第二層を ISO15627 (Data Link Layer for DSRC) を利用すればすべ てASLが利用でき，その結果として現存するプロファイル についてはIP接続が可能となる道が開けた. 今後もITUと ISOの役割分担を考慮した国際標準の開発が重要なテーマ と思われる。

\section{4．ITSと映像情報}

ITSは今までに述べたように多様であるが，一番課題が
多いのはドライバとの関係であろう。つまりドライバにい かに適切なタイミングで必要な情報を伝達し, ドライバの 判断をいかに自動車の運転という形で実現するかというこ とである，運転に関する判断は，命に関わることでもある ので, ドライバとのインタフェースは重要であるとは認識 されているものの, 分析手法が確立しているわけではない.

ITSで映像情報が使われている例を整理してみると表5の ようになる.ここではこの中から, カーナビのような画面 を利用してさまざまの情報を提示する場合に限って議論を 進めたい。

現在, 自動車の中でドライバに情報伝達する方法は基本 的には二つで, 聴覚と視覚を利用したものに分類できる. 振動, ステアリング反力等, 他の手法による情報伝達も実 験的には検討されている2) 4).

聴覚と視覚についての研究は, 生理, 心理の面から膨大 な実績があるが, 高速で走行中のドライバに, 運転に必要 な情報を短時間で適確に伝達するための聴覚・視覚情報の あり方については，ITSの普及によって，むしろ顕在化し てきた課題で, 心理学や生理学の分野に直接的な解答があ 


\section{現在までに発行されたISO国際標準}

\begin{tabular}{|l|l|l|}
\hline WG1 & ISO14817 & 「TTS/TICS中央データレジストリとデー夕辞書の要件」(2002/12) \\
\hline
\end{tabular}

ITSのシステム間で広く活用される標準的なデー夕の定義を共通辞書として登録管理する仕組みの規定.今後,相互運用性確保,開発効率化などに役立つことが期待される.

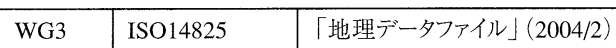

ナビゲーション等で使う地理データベースのデータ交換のための標準.本標準のフォーマットで記述されることにより,世界各地で作成された地図データが,世界中の地図ベンダー

間でナビゲーション等のデータとして流通できる.

\begin{tabular}{l|l|l|l|l}
\hline WG5 & ISO14906 & 「EFCから見たDSRCへのアプリケーションインタフェースの定義」(2004/9) \\
\hline
\end{tabular}

DSRC方式でのEFCアプリケーション・インタフェースを規定.日本や,最近の多くの欧州のETC車載器や路側機がこの規格を採用.日本のETC車載器は,2004年9月現在377万台 に達している.

\begin{tabular}{l|l|l|l|l} 
WG10 & ISO14819-1 & 「交通メッセージコードを経由したTTIメッセージ・パート1」(2003/6) \\
\hline
\end{tabular}

RDS-TMC (FM放送による旅行者情報のメッセージコード化)システムの導入部分を規定ドライバが国境を通過してもバーチャル言語の使用により自国語で交通情報の提供を 受けることが可能になる.

\begin{tabular}{l|l|l|l|l}
\hline WG10 & ISO14819-2 & 「交通メッセージコードを経由したTTIメッセージ・パート2」(2003/6) \\
\hline
\end{tabular}

RDS-TMCシステムに使用する旅行者情報メッセージの集大成.イベント情報のコード化方法を規定.14819シリーズ規格の中心的存在として異なるシステム間のメッセージ交換 の相互運用性の確保に貢献する.

\begin{tabular}{l|l|l|l|l} 
WG11 & ISO15075 & 「ナビメッセージセッ」(2003/12) \\
\hline
\end{tabular}

車載ナビシステムが取り扱うメッセージセットの必要事項の規定.北アメリカ・日本の既存規格をベースに作られ,経路誘導システムに適用可能な仕様.道路交通情報を考慮した 経路誘導サービス規格の検討などに用いることができる.

\begin{tabular}{l|l|l|}
\hline WG14 & ISO15622 & 「車間距離制御システム $(\mathrm{ACC})\rfloor(2002 / 10)$ \\
\hline
\end{tabular}

日本の交通実態調查,人間の反応時間の実験検討,安全性評価を踏まえ,最小車間時間と推奨車間時間,自動ブレーキ性能などを規定.実際に使用されるさまざまな走行環境 を想定したシステムの性能評価方法·基準を詳細に規定.(H12年度JS化)

\begin{tabular}{l|l|l|l|l}
\hline WG14 & ISO15623 & 「前方車両追突警報システム $(\mathrm{FVCWS}) 」(2002 / 10)$ \\
\hline
\end{tabular}

日本が規格原案を作成し,人間の反応時間を考慮した先行車両検知範囲,警報発生精度などの検討を行い,システム性能を規定.誤警報に対してはさまざまな走行環境を想 定して,評価方法·基準の規格に反映. 警報の表示方法などヒューマンインタフェースに関する事項も具体的に記述. (H12年度JS化)

\begin{tabular}{|l|l|l|l|l}
\hline WG14 & ISO17386 & $\lceil$ 車周辺障害物警報 (MALSO)」(2004/7) \\
\hline
\end{tabular}

初期規格原案に対して,我が国ですでに商品化が進んでいるバックソナー等の実態を踏まえたものとするため,システムの性能評価試験方法やそれに使用するための試験目標 物の調査研究を行い,規格に反映させた.

まもなく発行されるISO国際標準 (2005年2月現在)

\begin{tabular}{|l|l|l|l|l|l|}
\hline WG4 & FDIS14815 & 「車両·積載物自動認識システムのためのシステム要件」 \\
\hline
\end{tabular}

車両·積載物自動認識システムにおいて,対象車両·積載貨物の通過速度の規格と地上機器間距離の規格を定義することにより,発注者と受注者間の整合性をとり,相互運用 をしやくした.

\begin{tabular}{l|l|l|l|l}
\hline WG4 & FDIS14816 & 「車両·積載物自動認識システムのためのデー夕要件」 \\
\hline
\end{tabular}

車両·積載物自動認識システムに执て, 路側と通信する車両ID,車両情報や積載荷物情報(荷物ID,数量)のデー夕構造を規定することにより,相互運用性を確保した.

\begin{tabular}{l|l|l|l|l}
\hline WG9 & FDIS14827-1 & 「TICSセン夕間通信のためのメッセージ形式の規定」 \\
\hline
\end{tabular}

交通管理セン夕間での情報交換する際の交通情報(メッセージ)の形式,挍びメッセージを交換する際の手順(プロトコル)を規定し,相互運用性を確保した.

\begin{tabular}{l|l|l|l|}
\hline WG9 & FDIS14827-2 & 「TICSセンタ間通信のためのDATEX-ASNによる通信の規定」 \\
\hline
\end{tabular}

交通管理セン多間の情報交換の手順として,DATAX-ASNというプロトコルを規定したことにより,米国,欧州,日本ともに共通の国際標準とする形に修正した.

\begin{tabular}{|l|l|l|l}
\hline WG10 & FDIS14819-3 & 「交通メッセージコードを経由したTTIメッセージパート3」 \\
\hline
\end{tabular}

RDS-TMCシステムに使用する旅行者情報について,道路名称,街路名,市街地など位置参照情報のコード化方法を規定.ISO14819-1,ISO14819-2と並んで相互運用性の確 保に貢献する.

\begin{tabular}{|l|l|l|l|l}
\hline WG15 & FDIS15628 & 「狭埇第7層」 \\
\hline
\end{tabular}

DSRC第7層を規定.日本が規格原案を編集し,日本のDSRC規格(ARIB STD-T75)の第7層に準拠.日本や多くの欧州のETC車載器や路側機がこの規格を採用している. \begin{tabular}{|l|l|l}
\hline WG16 & FDIS15662 & 「プロトコルマネジメント情報」 \\
\hline
\end{tabular}

サービスセンタとユーザ端末間の中広域通信システムに扑るITSアプリケーションのメッセージに関するチェックリストの標準化.規格原案を日本が中心に作成した.

るわけではない，例えばカーナビや運転支援システムを想 定した場合，音声情報と画像情報を中心に，これらを組合 せた複数の方法で情報を伝達する必要があることが知られ ている( 5).

カーナビの画面は膨大な情報を含むものであるが，運転 という環境下で考えると，画面に表現されている事項に関 してはドライバが何らかの知識を持っているため, ドライ バは自分に必要な情報を取捨選択していると考えられる。
したがって画面の持っている情報量だけから使いやすさを 判断することはできない，言葉を変えれば，ドライバの運 転方略に一致あるいは関連した情報であれば, 認知が容易 になると思われる。したがって実験心理でよく行われる三 角形や四角形の単純図形を弁別する実験を, 運転中の環境 に持ち込めたとしても，この結果だけから，ドライバの運 転時の運転に関する情報処理能力を類推することは困難で あると考えられる67). 
表5 ITSに関連した映像情報メディアの例 （自動車の部分につしては文献8）9）を参考に作成）

\begin{tabular}{|c|c|}
\hline 自動車 & $\begin{array}{l}\text { ·運転支援用情報提供 (夜間視認性向上支援システム, ブライン } \\
\text { ドコーナーモニタ, インテリリジント駐車アシストシステム) }\end{array}$ \\
\hline & $\begin{array}{l}\text { ·カーナビを用いた情報提供 } \\
\text { 道路交通情報・警報用として(VICS等) } \\
\text { テレマティクス用として(店舗案内等) }\end{array}$ \\
\hline 路側機器 & $\begin{array}{l}\cdot \text { 交通流監視用画像センサ (交通量, 速度, 事故等) } \\
\cdot \text { 路側環境モニタ用画像センサ (気象, 事故, 災害等) }\end{array}$ \\
\hline 管制センタ & ·交通管制用画像モニ夕 \\
\hline
\end{tabular}

逆に言えば，ドライバによって運転方略には差があるの で，これに対応した音声，画像情報をどのように提示する かというのが課題である. 高齢化社会に突入した日本では, 統計を見るまでもなく, 高齢者による事故が増大している. 高齢者用の対策となると, 文字の大きさや図形の色等の工 夫が第一と考えられているが，実は運転方略が若いドライ バと異なると考えられており，このことをべースにした設 計が今後の課題と思われる.

以上のことから, 音声, 画像, 音声 (音) + 画像による車 内における情報提供は, ドライバの運転方略に対応してい るかどうかという点から検証する必要がある. カーナビ画 面の設計および評価の方法は認知心理, 実験心理で開発さ れた種々の手法が利用されているとともに，コンピュータ のヒューマンインタフェースの設計思想を参考に開発され た経緯がある。しかしながら，運転というきわめて限られ た状況におけるインタフェースの設計ということから，前 述したようなさまざまな問題が明らかになり，独自のアプ ローチが必要になってきた。

一方, 運転中の情報機器の利用について関心が高まって きたにもかかわらず，映像情報メディアの設計とHMI (Human Machine Interface) の成果が必ずしもリンクして いないように思う. HMIの分野では与えられた映像情報デ バイスのもとでのみ, ドライバとのインタラクションを考 察しているのが実態であろう.両方の技術のコラボレーシ
ヨンが今後, ITSの発展のために重要であると考えている.

コラボレーションを実現する手段として, 自由に画面の 大きさ, 解像度, 映像情報が変えられるHMI実験用のテス トベッドがつくれないだろうか. もしこのようなテストベ ッドができれば, ITSのHMIに関する研究は飛躍的に進み, 映像情報メディアの設計に多くの知見を与えることにな る.今後このようなコラボレーションが実現することを願 っている.

(2005年3月7日受付)

\section{〔文 献〕}

1) Architecture Development Team; "ITS Mission Definition", Prepared for the FHWA, US DOT, Washington DC (2002)

2) N.D. Lerner, B.M. Kotwal, R.D. Lyons and D.J. Gardner-Bonneau: "Preliminary Human Factors Guidelines for Crash Avoidance Warning Devices", DOT HS808 342 Interim Report, NHTSA (1996)

3）日本自動車研究所：“新エネルギー・産業技術総合開発機構委託業務 成果報告書”，基準創成研究開発事業，人と機械のインタフェース構 築のための情報提供技術に関する標準化（Mar. 2002）

4) Y.Miichi, S. Motoyama. T. Ohta, T. Watanabe and A. Shin: "Development of Mitsubishi Driver Support System", Proceedings of 6th ITS World Congress (CD-ROM) (1999)

5）麻生勤, 伊藤敏行：“地図ナビとTurn-by-Turnナビの比較研究”, シン ポジウムカーナビ・携帯の利用性と人間工学, pp.107-108（2000）

6）大門樹：“ドライバのストラテジーと車載情報システム”, オペレー ションズ・リサーチ，45, 7, pp.319-323 (2000)

7) 大門樹, 川嶋弘尚：“経路誘導機における認知工学的研究”, 電気学 会研究会資料, 道路交通研究会, RTA-95-1 12，pp.77-86（1995）

8）大江準三：“自動車における情報通信技術の流れ，前編”，情処学誌, 45, 9, pp.944-949 (2004)

9）大江準三 ; “自動車における情報通信技術の流れ，後編”，情処学誌, 45, 10, pp.1050-1056 (2004)

10) ITSホームページ, http://www.mlit.go.jp/road/ITS/j-html/, あるいは, http://www.jice.or.jp/itslist-j/, 米国のアーキテクチャについては, http://itsarch.iteris.com/itsarch/html/static/key_b.htm

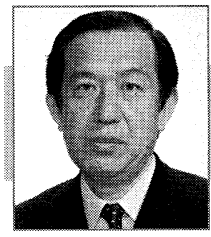

川岾鳥 弘尚尚 1973年, 慶應義塾大学大学院博士 課程修了. 1972年, 同大学助手を経て, 1992年より, 同大学理工学部教授. ITSに打けるヒューマンイン タフェースの設計・評価システム信頼性解析等の 研究に従事. ITS標準化委員会委員長 (ISO/TC204対 范)，ITS情報通信システム推進会議研究開発部会部 会長. 